.T79

Copy 1

SB 3

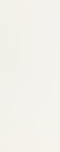

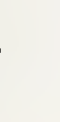

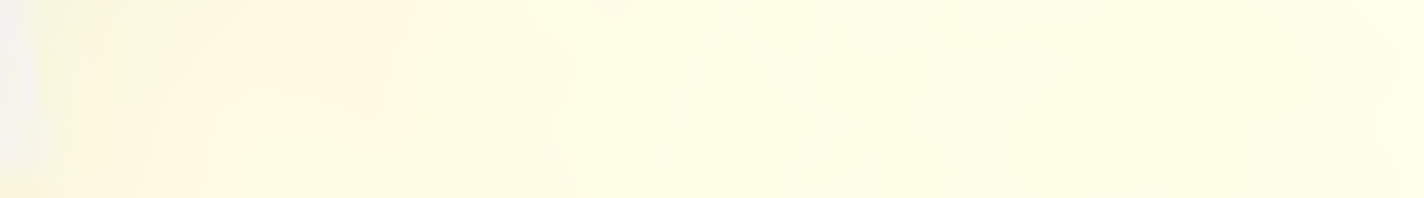

列 



\title{
UNITED STATES GRADES FOR BERMUDA ONIONS
}

\section{RECOMMENDED BY THE UNITED STATES DEPARTMENT OF AGRICULTURE}

\author{
HARTLEY E. TRUAX \\ Investigator in Marketing
}

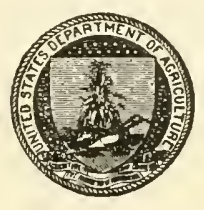

UNITED STATES DEPARTMENT OF AGRICULTURE DEPARTMENT CIRCULAR 97

\section{Contribution from Bureau of Markets GEORGE LIVINGSTON, Chief}




\title{
UNITED STATES GRADES FOR BERMUDA ONIONS.
}

\author{
Recommended by the United States Department of Agriculture.
}

The Bureau of Markets of the United States Department of Agriculture recommends the following grades as a standard for grading and marketing Bermuda onions in the United States. They are the result of inrestigations by the United States Bureau of Markets covering a period of four years.

Grades for Texas Bermuda onions were recommended in the spring of 1918 by the United States Bureau of Markets, promulgated by the 35th Texas State Legislature, and used as a basis for inspection by the Texas State Department of Agriculture and by the Food Products Inspection Service of the United States Bureau of Markets. For two seasons the operation of these grades was observed by the representatives of the Bureau of Markets and the investigations were extended into California and Florida. As a result of these investigations, some changes have been made in U. S. Grade No. 2, U. S. Grade Boiler's, and U. S. Grade No. 3, which, it is believed, will make the grades satisfactory standards for the Bermuda onion trade.

\section{U. S. Grade No. 1.}

U. S. Grade No. 1 shall consist of sound onions of one variety which are mature, bright, well-shaped, free from doubles, splits: bottle-necks, and seed-stems, and practically free from damage caused by dirt or other foreign matter, moisture, sunburn, cuts, disease, insects, or by mechanical or other means. The diameter shall not be less than two inches.

In order to allow for variations incident to commercial grading and handling, six per centum by weight of any lot need not meet the foregoing requirements of this grade. In the case of yellow onions, not more than five per centum by weight of any lot may be noticeably pink.

If any lot which meets the requirements of this grade contains unore than ten per centum by weight of onions with a diameter of three and one-half inches or more, the grade name shall be "U. S. Grade No. 1 Large."

\section{U. S. Grade No. 2.}

U. S. Grade No. 2 shall consist of sound onions of one rariety not meeting the requirements of U. S. Grade No. 1, which are free from doubles, splits, bottle-necks, and seed-stems, and practically free from 
damage caused by moisture, sumburn, cuts, disease, insects, or mechanical means. The diameter shall not be less than two inches.

In order to allow for variations incident to commercial grading and handling, ten per centum by weight of any lot may be below the requirements of this grade.

If any lot which meets the requirements of this grade contains more than ten per centum by weight of onions with a diameter of three and one-half inches or" more, the grade name shall be "U. S. Grade No. 2 Large.'

If any lot which meets the requirements of U. S. Grade No. 2 or T. S. Grade No. 2 Large contains more than ten per centum by weight of noticeably pink onions, the grade name shall be "U. S. Grade No. 2 Pink" or "U. S. Grade No. 2 Large, Pink," as the case may be.

\section{U. S. Grade Boilers.}

U. S. Grade Boilers shall consist of sound onions of one variety which are free from doubles, splits, bottle-necks, and seed-stems, and practically free from damage caused by moisture, sunburn, cuts, disease, insects, or mechanical means. The diameter shall not be less than one inch nor more than two inches.

In order to allow for variations incident to commercial grading and handling, six per centum by weight of any lot may be below the requirements of this grade.

\section{U. S. Grade No. 3.}

U. S. Grade No. 3 shall consist of onions which do not meet the requirements of any of the foregoing grades.

\section{Definition of Grade Terms.}

As used in these grades:

"Sound" means free from water-soaked, decayed, sprouted, or otherwise unsound onions.

"Mature" means having reached a stage of development at which the onions are firm-not soft or spongy.

"Bright" means having the normal, attractive, pearly luster of Bermuda onions.

"Well shaped" means having the general appearance of being round-not three, four, or five sided, or badly pinched by dry, hard soil, or thick necked, but need not be of the exact, typical flat Bermuda shape.

"One variety" means one variety or type, such as the Crystal Wax or White Bermuda (white), or Yellow Bermuda (yellow), and not a mixture of different varieties or types.

"Practically free from damage" means that the appearance shall not be injured to an extent readily apparent upon casual examination.

"Sunburn" means discoloration or other damage due to exposure to the sun, but does not mean the green color running down the 
4 Department Circular 97, U. S. Dept. of Agriculture.

"veins" in the Crystal Wax or White Bermuda (white) variety unless such green color covers the surface between the veins.

"Diameter" means the greatest dimension at right angles to a straight line running from the stem to the root.

"Noticeably pink" means the pink color often found in the Yellow Bermuda variety which is so conspicuous as to be readily apparent upon casual examination of the lot.

ADDITIONAL COPIES

OF THIS PUBLICATION MAY BE PROCURED FROM

THE SUPERINTENDENT OF DOCUMENTS

GOVERNMENT PRINTING OFFICE

WASHINGTON, D. C.

AT

5 CENTS PER COPY 

LIBRARY OF CONGRESS

Metal Edge, Inc. 2006 P.A.T. 